\title{
The European Commission
}

\section{Hussein Kassim}

\section{Summary}

Novel in both design and function, the European Commission occupies a central position in the political system of the European Union (EU). Compared to other international administrations in other international organizations, its responsibilities are extensive. The Commission is the principal source of EU legislative initiatives. It manages EU policy and processes, monitors the implementation of EU law, and negotiates trade agreements on the EU's behalf. Though often decried as an "unelected bureaucracy," the Commission is in fact a hybrid body. Whereas the services of the Commission form a permanent administration, the College, headed by the Commission president, is political. Members of the College, including the president, are appointed by the governments of the member states and elected by the European Parliament every five years, following popular elections to the latter body.

The internal functioning of the Commission has attracted considerable interest, particularly among scholars of public administration and comparative politics. With respect to the Commission's functioning within the wider EU system, the main debates relate to the role of the institution in the EU's development; the extent of its influence over policy; its executive responsibilities and interaction with agencies at EU and national levels; and, in the context of a wider discussion of the EU's democratic credentials, the Commission's accountability. Few dispute the Commission importance, but there is considerable disagreement on how the Commission's role in integration should be theorized and how the Commission as a body should be conceptualized.

\section{Keywords}

European Commission, European Union administration, Eurocrats, bureaucracy, bureaucrats, presidentialization, coordination, agent, European Union politics 


\section{The European Commission}

\section{Hussein Kassim}

\section{Introduction}

The European Commission has been an object of enduring fascination. The responsibilities entrusted to it under the founding treaties involve the Commission in all areas and at virtually every stage of EU decision-making. More than an international secretariat but less than a government, it has attracted considerable and sustained attention in virtue of its institutional novelty, centrality to the EU, and influence within and beyond the borders of the Union. Of all EU institutions, the Commission is most often treated as synonymous with "Brussels" or "Europe," and the one that arouses the most controversy. Conforming to Jean Monnet's conception of an independent arbiter of European interest and declared by Walter Hallstein as to be the "most original and unprecedented of institutions," the Commission was, according to Charles de Gaulle, populated by "pretentious technocrats," while a former British Foreign Secretary, Douglas Hurd vilified Commission staff as "faceless bureaucrats bent on centralization and involvement of every nook and cranny of national society." Political leaders have disagreed over how much power it should have and what kind of administration it should be, while scholars have debated how much influence it exerts and how it functions, raised questions about its accountability, legitimacy and authority, and speculated about the people who work for it. More broadly, in a populist age, the perception of the Commission as a remote bureaucracy or an unelected government has gained ground among European publics.

Against this background, the purpose of this article is twofold: to provide an overview of the Commission as an institution, highlighting both its role within the EU system and describing its characteristics as an administration; and to offer a critical overview of debates concerning the Commission in the research literature. Although the key books on the organization have appeared in waves (Cini, 1996; Coombes, 1970; Ellinas \& Suleiman, 2012; Georgakakis, 2012, 2017; Hartlapp, Metz, \& Rauh, 2014; Hooghe, 2001; Kassim et al., 2013; Page, 1997; Stevens \& Stevens, 2001; Wille, 2013), the scholarship on the Commission is now voluminous. It is written from several disciplinary and sub-disciplinary perspectives, 
including international relations, comparative politics, public administration (Trondal, 2007), and sociology, and varies in approach, method, and technique.

The discussion that follows is organized into three parts. The first describes the aims of the treaty signatories in their design of the Commission, outlines the Commission's functions and responsibilities, and summarizes the changes the Commission has experienced. The second section focuses on the Commission as an administration. It examines the structure, organization, and operation of the Commission, as well as its personnel policy and the people who work for it. The third places the Commission within the wider EU system. It considers how the Commission's role in decision-making, as well as its relationship with other institutions and actors in the EU system, has been theorized, conceptualized, and investigated.

\section{Origins and Responsibilities}

The Commission was created under the 1957 Treaty of Rome as the executive body of the European Economic Community, one of the three original European Communities. Its counterparts were the High Authority of the European Coal and Steel Community, established by the Treaty of Paris, 1951, and the Commission of the European Atomic Energy Community, created by the EURATOM Treaty, 1957. The three executives were merged in 1967 to form the Commission of the European Communities (see Laursen, 2019). In the powers and responsibilities that they vested in these executive bodies, the signatories departed from the traditional design of international bodies. International organizations are typically intergovernmental. Ultimate decision-making authority is exercised by a body composed of senior representatives of the member countries, governments are subject only to decisions that they support, and the international administration-typically, an international secretariat - although permanent, is a subordinate body, with limited functions, responsibilities, and influence. In the case of the Communities, the framers gave the permanent institutions roles that ensured their centrality in the operation and development of the organization, and the authority to carry out their responsibilities independently of the member states. 
The supranationality of the three executive bodies differentiated them from other international administrations and distinguishes the three original Communities from other international organizations (see Bauer \& Knill, 2016; Rittberger \& Zangl, 2012; Siotis, 1964). The framers were particularly concerned that the Communities should avoid the pathologies of the traditional intergovernmental model. Their design was intended to ensure that the ambitions set out in the treaty were realized, that governments would not (be allowed to) defect from their obligations, and that the Communities would not become enmired by national differences or fall victim to the national veto.

There were significant differences between the executives, however. Although the framers of the Paris Treaty had conceived the High Authority as an incipient government, their ambitions for the Commission of the European Economic Community were more modest. Drawing on the experience of the European Coal and Steel Community (ECSC) in action and learning from the defeat of the European Defence Community and the European Political Community, the Commission was granted few direct powers. In addition, whereas the ECSC had outlined specific policies that were to be implemented in coal and steel, the Rome Treaty was a "framework treaty" (Noel, cited in Dumoulin, 2007), which defined goals and objectives, but left to the institutions the work of deciding and adopting policies.

The four responsibilities vested in the Commission nonetheless gave it a central role. First, it was granted a monopoly over policy initiation. All decisions were based on a Commission proposal, which led to the description of it by commentators as the "motor of integration." Second, it was the Community's executive body, responsible for the management and implementation of EU policies. Third, the Commission was "guardian of the treaties," responsible for monitoring compliance with EU rules and taking action where it was suspected that governments and others failed to meet their obligations under EU law. Its fourth function was to represent the Community in external economic relations, including bilateral and multilateral trade negotiations.

These core responsibilities have remained more or less unchanged since the late 1950s, although the Commission has had continually to adapt to new demands and an everchanging environment. With successive waves of enlargement that increased the number of EU's members from 6 to nearly 30, and the broadening of the EU's competencies, the 
Commission has become a larger and more complex organization. From a staff of 5,273 in 1970 , it had grown to 7,813 in 1975 ; to 10,429 in 1985 ; to 15,568 in 1995 ; and to around 32,000 in 2019 (European Commission, 2019).

The EU system has also changed very significantly since the early 1960s. Processes such as the consolidation of the Council of the European Union, the emergence of the European Council (Puetter, 2014), the strengthening of the European Parliament (Rittberger, 2005), and the multiplication of European agencies (Chamon, 2006), whether the result of formal treaty change, secondary legislation, or institutional assertion, have increased the EU's institutional and organizational complexity. They have also altered the Commission's status, powers, and terms of interaction with other actors. Some have argued that the Commission has declined in consequence (Bulmer \& Wessels, 1987; Johnston, 1994; Kassim \& Menon, 2010), although this view has been contested (Nugent \& Rhinard, 2016).

Finally, the Commission has enacted two important administrative reforms. The so-called "Kinnock reforms," implemented between 1999 and 2004, were applied in the wake of the resignation of the Santer Commission amid allegations of corruption and nepotism leveled at the Commission and following the subsequent commitment on the part of the incoming Commission president to modernize the organization. The reforms were the most comprehensive undertaken by the Commission and included the creation of a central planning and programming apparatus, a far-reaching staff reform, and an overhaul of financial management and control procedures (Bauer, 2008b; Kassim, 2004a, 2004b, 2008; Kassim et al., 2013; Levy, 2004; Schön-Quinlivan, 2011; Stevens \& Stevens, 2001). The 2014 reform, applied under the conditions of austerity that followed the financial and economic crisis, were narrower in scope. However, as well as changes in entitlements and conditions, they included a wage freeze and a year-on-year staff reduction (Connolly \& Kassim, 2015a; European Court of Auditors 2019).

\section{Inside the Commission}

The organization of the Commission further distinguishes it from international secretariats. The Commission is a hybrid, combining a political body, the College, which leads the organization and an administration, the "services," which are responsible for technical, 
preparatory, and support work. Although each College is in office for a fixed term (initially, four years but since 1995, five years), the workforce in the services is composed predominantly of permanent civil servants.

\section{The College}

The Treaty sets out the rules governing the composition of the College and specifies the method by which its members are appointed. It also requires commissioners to be independent, which is symbolized by their commitment as part of the oath they make, on taking office, "neither to seek nor to take instructions from any Government or from any other institution, body, office or entity." The College is composed of one commissioner per member state, each of whom is assisted by a private office or cabinet. To symbolize that the College represented the general interests of the EU (Dimitrakopoulos and Kassim, 2005), the Commission's first president, Walter Hallstein, determined that decisions should be taken collectively at a weekly meeting devoted to that purpose. The Wednesday meetings of the College set the rhythm for the work of the Commission (Tholoniat, 2009) and inform the organization of its supporting structures-the Monday meeting of chefs de cabinet and the meetings of sectoral experts from the cabinets (the so-called, "special chefs") held where necessary in the preceding week, to consider issues that cannot be reconciled at a technical level.

The rules and procedures governing the composition of the College and its appointment have developed significantly since the Treaty of Rome. Three changes are particularly noteworthy. First, the Treaty of the European Union increased the term served by the College from four to five years in order to align it with the electoral cycle of the European Parliament and thereby strengthen the Commission's accountability to the Parliament. Second, the entitlement of larger member states to each appoint two commissioners, and of the smaller states each to appoint one, grew increasingly unsustainable as the College became large and unwieldy (Spierenburg, 1979). With further accessions on the horizon, governments agreed to include a stipulation in the Nice Treaty that once the number of Commissioners reached 27, the size of the subsequent College would be reduced to below 27. However, because a decision on what formula to implement proved elusive, governments agreed as a transitional measure that the larger member countries would each 
give up their second commissioner. This provision took effect in the first Barroso Commission.

Third, commissioners were initially appointed by the common accord of the member states' governments, who also decided the allocation of portfolio responsibilities. The selection procedure for the Commission president was originally similar to that of other members of the College. The only difference was that governments reviewed and could reselect the Commission president midway through the College's four-year term. Since the Treaty of European Union, however, the procedure for choosing the Commission president has been gradually separated from the selection of other members of the College. Under the Lisbon Treaty, which entered into force in 2009, the candidate Commission president is selected by the European Parliament and European Council following elections to the European Parliament (Christiansen, 2016). If confirmed, he or she then chooses members of the Commission from the nominees put forward by national capitals. The political standing of the individual concerned - the strength of his or her mandate, former positions held, and political experience-as well as the willingness of member governments to accept a steer, nominate more than one candidate, or put forward another name when the first is refused determines in practice how much discretion the Commission president-elect can exercise over the composition of his or her team.

Though distinct processes, the election of the Commission president and the appointment of commissioners have been both parliamentarianized and presidentialized. The process of parliamentarianization began when the Treaty of European Union gave the European Parliament the right to be consulted on the appointment of the president and the authority to approve the College en bloc. The Parliament took advantage of the latter provision by inserting in its rules of procedure the requirement for hearings of the commissionersdesignate that were modeled on the "confirmation hearings" held by the U.S. Congress on presidential nominations to judicial and executive posts. The Parliament has used this power to secure changes to the composition of the College. In 2019, for example, it vetoed the original nominees put forward by the French, Hungarian, and Romanian governments. The powers of the Parliament were extended by first by the Amsterdam Treaty, which gave Parliament the right to approve the member states' nominee for Commission president. 
When the Nice Treaty granted the European Council the power to nominate the Commission president, the Parliament retained the same right of approval. The Treaty of Lisbon gave Parliament the authority to elect the president of the Commission on the basis of a proposal from the European Council that takes into account the results of European Parliamentary elections. This provision was the basis for the Spitzenkandidaten process, where a number of the major European parties, backed by the European Parliament (EP), agreed in the interests of enhancing the Commission's democratic legitimacy that the candidate of the party that won the 2014 European elections should become the Commission president (Christiansen, 2016; Westlake, 2016). Five of the EP's main party families - the Party of European Socialists (PES), the European People's Party (EPP), the Alliance of Liberals and Democrats in Europe (ALDE), the Party of the European Left, and the European Green Party-each duly selected, either via a primary or another procedure, a candidate who featured prominently in their campaigns. Following the elections, the parties insisted that, because the EPP had won more votes than any other party, they would veto any nomination by the European Council other than Jean-Claude Juncker, the EPP's chosen candidate (Kassim \& Laffan, 2019). The European Council, which had been opposed to the Spitzenkandidaten process, insisting that the power to nominate the Commission president lay with heads of state and government, backed down in the face of considerable pressure. It voted by qualified majority to appoint Juncker as Commission president. Juncker then faced another vote before the European Parliament, which he won, and thereby he became Commission president. Despite strong support for the Spitzenkandidaten process in the EP, Manfred Weber was not put forward as its nominee in 2019, even though he had been the lead candidate of the political family - the EPP—-that finished ahead in the polls. On this evidence, the European Council appears to have wrested back its power.

The appointment of commissioners has also been presidentialized-one of several ways in which the Commission presidency has been strengthened (Kassim, 2012). Before the Santer administration (1995-1999), the Commission president had virtually no influence on the selection of commissioners or the allocation of portfolios (Delors, 2004;Tugenhadt, 1986). Since Maastricht, that has changed. The Treaty of European Union required governments to nominate other members of the Commission "in consultation with" the nominee for Commission president, which the Amsterdam Treaty changed to "by common accord." 
Under the Nice Treaty, the Commission president acquired the power not only to reshuffle individual commissioners but to oblige them to resign. The Lisbon Treaty retained these powers. Although these changes mark a significant strengthening of the powers of the Commission president, it is important to underline that member states alone decide who to nominate; hence, Barroso's complaint that the Commission president has a "blind date" with the individuals chosen by national capitals.

\section{The Services}

The Commission administration is organized into departments or directorates-general (DGs), each of which is headed by a director general. DGs are further subdivided into directorates, and divisions or units, headed, respectively, by a director and a head of unit. The services have grown considerably since the first Commission, which was composed of nine directorates-general, an executive secretariat, and three joint services that the Commission shared with the High Authority and the Euratom Commission. Under the Juncker Commission (2014-2019), the departments included 34 directorates-general and 12 services. Most have responsibilities for policy areas, such as trade, fisheries, and transport. Others have horizontal or support responsibilities. Among the services, the SecretariatGeneral has always been primus inter pares on account of its coordinating role and recordkeeping responsibilities (Kassim, 2006). Seen traditionally as the guardian of collegiality, the Secretariat-General ensured that internal procedures were followed and all departments consulted. It was also regarded as the representative of the permanent administration to the political level (Kassim et al., 2013)

The Commission services are staffed by a career civil service, and in the continental tradition the conditions of service are codified in the Staff Regulations (or "Statut"). Recruitment is through an external competition, mainly at entry level, with the expectation of progression up the scale over the course of a career. Originally, staff were recruited into four categories, depending on their level of education, but in 2004 the Kinnock reforms introduced a new scale, which separated staff into ADs (administrators) and ASTs (assistants), and a more recent reform introduced a clerical AST category, SC (Connolly \& Kassim, 2015b). Both ADs and ASTs are officials, although in the literature the term "officials" is sometimes used (mistakenly) as a synonym for ADs. The permanency of its personnel distinguishes the 
Commission from most international administrations, and its creation ran contrary to preferences of de Gaulle and others who had wanted the Commission to be made up of national civil servants seconded on fixed-term contracts (Seidel, 2010). Hallstein (1965) had insisted, however, that only as "une grande administration" would it be able to rival national bureaucracies and command the respect necessary to carry out the functions that it had been entrusted under the founding treaties.

The principle of permanence has, however, been compromised in two ways. The first is by the demands of nationality. The Commission needs to ensure that it has within its workforce the expertise, skills, and experience necessary to carry out its functions, as well as to possess legitimacy as a representative bureaucracy in the eyes of EU citizens (Murdoch, Connolly, \& Kassim, 2018). The Commission is therefore committed to the principle of "geographical balance," whereby staff are drawn from all the member states (European Commission, 2018). It also requires that staff be recruited at all levels from the incoming member states with each enlargement, which inevitably diminishes the promotion prospects of existing staff. Although the member states originally insisted historically that their nationals should be present in the Commission administration in rough proportion to their share of the EU population, the demand proved impossible to meet in practice for rank-and-file positions. It was respected in senior management positions for over four decades, however, until the Kinnock reforms prioritized skills and experience over nationality as the key criterion for promotion to these positions.

Second, the Commission has had to develop over time a range of temporary staff categories to meet short-term needs or requirements for specialist expertise (Stevens \& Stevens, 2001) (see Table 1). Fixed-term contracts create difficulties for both the organization and individuals. For the Commission, there is a continual churn of temporary staff, the recruitment and replacement of whom absorbs resources and is disruptive for the affected departments, while for the employees themselves there is the frustration of being appointed to a post, learning the job, doing it well, but knowing that the opportunities for becoming a permanent official are limited. Seeing themselves as guardians of the European public service, the staff unions, moreover, have sought to restrict the possibilities for the transfer of staff from temporary to permanent status. Yet, temporary staff represent an 
important and sizeable segment of personnel, as testified by the profiles produced annually by the Commission's Directorate-General for Human Resources and Security.

\section{The Internal Operation of the Commission}

Leadership in the Commission, the interaction between and among cabinets and the services, and the people who work for the organization have all attracted scholarly attention. Several books examine the whole administration (Cini, 1996; Coombes, 1970;

Dimitrakopoulos, 2004; Kassim et al., 2013; Nugent \& Rhinard, 2016; Schön-Quinlivan, 2011; Smith, 2004; Spence \& Edwards, 2006; Stevens \& Stevens, 2001; Wille, 2013). Other studies consider particular actors-presidents (Kassim, 2012; van der Harst and Voerman, 2016), commissioners (Deckarm, 2017; Joana \& Smith, 2004), senior staff (Ellinas \& Suleiman, 2012; Hooghe, 2001), cabinets (Deckarm, 2017; Joana \& Smith, 2002), middle managers (Bauer, 2008b) - or individuals, notably Jenkins (Ludlow, 2016) and Delors (Drake, 2000; Endo, 1999; Ross, 1995). A number discuss informal networks in the Commission (Suvarierol, 2007, 2009), and Hartlapp et al. (2014) investigate internal policy making. Leadership

The Commission's political leadership has been a topic of long-standing interest. Despite the high visibility of the Commission President and the expectations directed towards its incumbent, the powers granted it under the treaty were sparse and commitment to collective decision-making added a further constraint. This led one biographer of the former European Commission President (1977-1991), Roy Jenkins, to describe it "an impossible job. Indeed, ... hardly ... a job at all" (Campbell, 1983, p. 181). Only Hallstein (1958-1968) and later Jacques Delors (1985-1995), exceptionally, were able to transcend the limitations of the office. Whereas Hallstein, the first Commission president, was able to rely on a unique sense of common purpose among his colleagues, Delors arrived in Brussels with strong backing both from Bonn and Paris, which gave him a mandate and equipped him with farreaching personal authority (Grant, 1994; Ross, 1995).

Until the changes enacted first by the Amsterdam Treaty, and especially the Nice Treaty, the Commission Presidency was scarcely differentiated from other members of the Commission. The office lacked the political resources-an electoral mandate, leadership of a political 
party, or coalition agreement-from which heads of government typically derive their authority. The incumbent originally had no powers of appointment over other members of the Commission. The presidency also had few procedural resources. Decisions were taken collectively by the College, the president had no special powers over what items to include or exclude from the agenda, and, unlike for example British prime minister, he or she could not delegate decision-making power to subcommittees of the College and thereby circumvent opposition. The Commission president also had limited administrative resources. The president's cabinet was not significantly bigger than other Commissioners. Although the Secretariat-General was formally accountable to the president, its responsibilities were to the College and Commission as a whole (Kassim, 2006). Moreover, the president had little if any personal authority over Commission services. Decisions concerning the organization of the Commission were taken by the College as a whole. Nor was the College well placed to provide effective leadership. As result of the method by which they were selected, Commissioners were rarely united by common political purpose or ideological outlook (Coombes, 1970). Nor were members of the Commission subject to the same obligations, disciplines or incentives as a government minister. They did not owe their appointment to the Commission president nor (until the Nice Treaty) could they be dismissed. Relations between Commissioners were competitive as each sought to promote his or her own policy agenda in pursuit of personal political success. Unsurprisingly, Colleges lacked cohesion, discipline, and the authority to control or coordinate the services. A slow process of presidentialization has gradually created a capacity for effective leadership. The Presidency has been strengthened by a series of treaty amendments-the Treaty of Nice was arguably the key moment-in four ways: (a) by giving the Commission president the power to define the Commission's policy guidelines; (b) by explicitly recognizing the Commission president's pre-eminence within the College; (c) by granting the president authority over the organization of the Commission; and (d) by giving the president the authority to appoint, dismiss and re-shuffle individual Commissioners. Operationalized through the Commission rules of procedure, they have given the Commission presidents control over the Commission's policy and work programs, the weekly agenda of the College, and the organization of the Commission services. Previously, these powers had been in the collective hands of the College. 
José Manuel Barroso was the first Commission president to make extensive use of these powers (Kassim et al., 2013). Over his two terms of office, the first from 2004 to 2009 and the second from 2009 to 2014, he pursued a strongly presidential leadership style. Invoking the prerogatives of the office and the need for clear direction following the "big bang" enlargement to Central and Eastern Europe, and the rise of Euroscepticism, Barroso decided it was for the Commission president to define the Commission's policy priorities, determine what was discussed in College, and put his name to important proposals. To underpin this expanded conception of the presidency, Barroso gave the office a new organizational resource. By converting the Secretariat-General from its traditional function of serving the College as a body into a presidential service, Barroso was able to extend the reach of the presidency, and to use the Secretariat-General's presence at key procedural interstices to ensure the promotion of his policy agenda. The planning, monitoring and quality control mechanisms created within the Secretariat-General by the Kinnock reforms were harnessed to pursue the president's policy program.

The restructuring of the College undertaken by Commission president Juncker further strengthened presidential leadership (Kassim, 2017; Kassim \& Laffan, 2019). Juncker was not only the first president to be appointed through the Spitzenkandidaten process and therefore to be able to claim a personal mandate for his political program, but also the first incumbent to have at his disposal the full panoply of powers flowing from the Lisbon Treaty. Using the term "political Commission" to highlight his intention to lead an administration that would be responsive to the needs of European citizens rather than a remote, insensitive technocracy, turn the page on austerity, and operate differently from its predecessor, Juncker undertook a series of organizational and procedural reforms, introducing "new ways of working," that were intended to ensure the effective delivery of the policy program he set out before the European Parliament in his Political Guidelines (Juncker, 2014).

The reorganization of the College was carefully thought through during the transition period following Juncker's election in July 2014, by a team led by Martin Selmayr, who would head the President's cabinet and later become secretary general. The Juncker Commission (201419) was organized around seven vice presidents. Two-the first vice president and the vice 
president for the Budget and Human Resources-held cross-Commission responsibilities. The other five each took the policy lead in a designated field, and for steering the work of project teams composed of commissioners with the associated portfolio responsibilities. The aim was to strengthen political leadership in an effort to overcome the fragmentation that had historically characterized the organization and thereby ensure delivery of the Commission president's 10 policy priorities within the lifetime of the Juncker administration. Coordination

The emergence of a strong political and administrative center within the Commission since 2004 has greatly improved internal coordination, which had historically been highly problematic for the organization (Coombes, 1970; Cram, 1994; Kassim et al., 2013; SchönQuinlivan, 2010; Spierenburg, 1979). Horizontally, cabinets had been in fierce competition with each other, either to promote portfolio or national concerns (Joana \& Smith, 2002), whereas DGs were perceived as feuding baronies, fiercely fighting to defend their turf. Vertically, the relations between the cabinets and the services embodied the classic confrontation between political ambition and technical knowledge.

In the absence of a countervailing strong central authority, keeping these relationships in check had been a perennial challenge. The cabinets in particular had been viewed as a disruptive force within the organization (Donnelly \& Ritchie, 1997). Although they provided essential support for the Commissioners and served as an important intermediary between the political level of the Commission and the administration, they were regarded with suspicion by the services, first, because their key members were typically external recruits with little experience of the EU, second, because they too often interfered in the technical detail of policy, and third, because they were frequently constituted of compatriots of the Commissioner and acted as national enclaves promoting the interests of the Commissioner's national capital. Furthermore, towards the end of each mandate, cabinet members recruited from outside the organization would be "parachuted" into a middle or senior management post, thereby blocking the promotion opportunities of career officials. Many of these tensions have now been defused. Rules introduced by the Santer Commission and after require that cabinets be multinational in composition, that they include Commission officials on secondment as well as external recruits, and that they be 
gender balanced. There are also restrictions on parachutage. As a result of these changes, the cabinets have undergone a process of de-nationalization both in their composition (Egeberg \& Heskestad, 2010) and in their operation (Kassim et al., 2013). Maintaining the relationship with the Commissioner's capital is no longer perceived as a top priority, for example. Although tensions remain-members of cabinets do not believe that the services take sufficient account of political considerations, for example, while staff in the DGs do not think that the cabinets always treat them with sufficient respect-and the belief persists that cabinets and services live in different worlds, the relationship is no longer sharply conflictual.

\section{Commission Personnel}

Scholars interested in the people who work for the organization have examined the origins of Commission staff, their motivations and beliefs, and the socializing power of the Commission. Nationality has been an enduring concern-as a factor in appointments and promotions, in shaping the Commission's administrative culture (Stevens \& Stevens, 2001), and in determining the extent to which the Commission can be considered a representative bureaucracy (Murdoch et al., 2018). The impact of the 2004-2007 enlargements also attracted interest, given the need to suddenly introduce staff on an unprecedented scale from the acceding 12 member states (Ban, 2013; Kassim et al., 2013, chap. 9).

Early studies were somewhat fragmentary. Michelmann (1978), for example, had focused on only two DGs. It was not until the Prodi Commission that the Commission began to publish detailed breakdowns of its staff, and only after a further twenty-five years that the Commission published its understanding of the "geographical balance" (European Commission, 2018). Page (1997) was the first to investigate systematically the number and distribution of nationals within the Commission. Using a disproportionality index that measured the presence of each member state's nationals against that country's share of the EU population, he established that the nationals of many smaller member countriesparticularly Belgium for obvious reasons-were over-represented, whereas larger member states were under-represented. 
Two decades after Page's analysis the underrepresentation of certain member states not only persists, as Table 3 shows, but, following the 2004-2007 enlargements when it assumed a new salience, has become an issue for the Commission and the countries concerned (Connolly \& Kassim, 2015a). As well as the cause of a potential shortage of expertise, underrepresentation has a democratic dimension. The Commission needs to be visibly representative of the populations that it serves and able to communicate with European citizens in their mother tongue. There is also an anxiety that underrepresentation might be symptomatic of deeper problems. The declining number of U.K. nationals, for example, has been interpreted as a warning that low levels of recruitment signal decreasing levels of identification with the EU and understanding of it. The Commission has been keeping a close eye on the issue (European Commission, 2018). Gunther Oettinger, the commissioner responsible for administration in the Juncker Commission, the DirectorateGeneral for Human Resources, and the European Personnel and Selection Office, together with the member states concerned, have been investigating ways to improve recruitment from under-represented countries.

\section{[INSERT FIGURE 1]}

Although nationality has been a perennial scholarly concern, attention has more recently been directed at the educational and professional backgrounds of Commission staff (Connolly \& Kassim, 2015a, 2019; Kassim et al., 2013). Contrary to accepted wisdoms, these studies have reported that the Commission is not populated overwhelmingly by lawyers. In fact, there are more graduates of economics and of natural science than of law among its personnel. Nor is the Commission staffed only by career civil servants, with little experience beyond the public sector or outside the Brussels "bubble." In fact, no fewer than $97 \%$ of Commission personnel have significant previous work experience, whereas more than $40 \%$ have been employed in the private sector or the liberal professions (Alayrac, Connolly, \& Kassim, 2019).

Scholars have also examined the motivations, beliefs, and values of Commission staff. An assumption in the early literature was that the staff of EU executive bodies would be committed supranationalists (Haas, 1958). Later writers took the view that Commission staff 
are likely to be Niskanen-style competence maximizers (Hix \& Høyland, 2011). A common perception, meanwhile, shared by scholars and the wider public alike, is that the Commission personnel are likely to be committed federalists. Empirical tests of these views suggest, however, there is little evidence to support them. When in her pioneering study she investigated the outlook of senior managers and chefs de cabinet, for example, Hooghe (2001) found significant variation in the ideals and preferences of staff. These results were confirmed in later research based on data from much larger staff samples-1,901 policy officers in Kassim et al. (2013) and 5,545 from all staff groupings in Connolly and Kassim (2015a, 2015b). These studies report that "building Europe" is an important motivation on the part of most staff for deciding to pursue a career in the Commission, but that other reasons are also significant and that more employees prefer the "Community method" to a federalist vision of the future where the Commission is the government of Europe. Moreover, personnel do not necessarily instinctively prefer "more Europe" to "less Europe" (Hooghe, 2012).

A related question concerns influence on the values of Commission staff. The debate on whether the beliefs held by staff are the result of socialization within the Commission began with Hooghe (2005). In this influential article, Hooghe argued that although the beliefs of senior staff were aligned with the Commission's organizational values, those values were forged early in life-well before employees entered the Commission and therefore independently of it. This "pre-recruitment" thesis, which quickly became the dominant wisdom in the literature, was challenged by Trondal (2007). Trondal examined the views of seconded national experts, civil servants recruited to the Commission for a fixed term before returning to their home administration, and found that their experience in the Commission had had an impact on their loyalties. In other words, "post-recruitment" experience could shape the outlook of personnel.

More recently, Connolly and Kassim (2016) have revisited the socialization debate. They have tested the main hypotheses proposed in the literature, using a dataset drawn from Commission respondents in all staff groupings and in several locations. They show for the first time that the values of personnel vary between staff categories, thereby underlining the danger of grounding generalizations in the experience of a narrow segment or strata of 
personnel. Moreover, able to assess the effects of a far wider range of variables than the earlier literature, they find that staff values are shaped by experiences both before and after entering the Commission. Further analysis similarly confirms that the European Commission is a socializing environment, which runs counter to the established view in the literature that working for an international administration does not significantly affect the values of staff (Murdoch, Kassim, Connolly, \& Geys, 2019).

Finally, the question of whether an administrative culture exists within the Commission has divided scholars. Cram (1993) and Cini (1996) argue for the existence of shared norms and loyalties, but suggest that they are greater at departmental level than across the whole organization. This position is contested by Abélès, Bellier, and McDonald (1993); Shore (2000); and Ellinas and Suleiman (2012), who, for different reasons and writing from different perspectives, contend that there is evidence of a Commission-wide culture. Meanwhile, Ban (2013), Kassim et al. (2013), and Connolly and Kassim (2015a) take opposite views on whether staff from member states that joined the EU in 2004 and 2007 differ in their beliefs, values, and outlook from recruits from the EU15. Whereas Ban (2013) finds evidence of strong differences, Kassim et al. (2013) and especially Connolly and Kassim (2015a) find only a slight variation. Taking a somewhat different approach, Georgakakis (2017) argues that the Commission's administrative culture is in decline and that traditional norms have been eroded by managerial change that has effectively normalized the Commission.

\section{The Commission in the EU System}

A significant literature also investigates the function and operation of the Commission within the wider EU system, where scholars have been particularly concerned to assess the Commission's power and influence. Four debates can usefully be distinguished, even if in practice they overlap. The first concerns the Commission's role in integration. It originates in a clash between supporters of the two classic theories, neofunctionalism and intergovernmentalism, which, with the emergence of new theoretical perspectives in the 1990s, became a debate between intergovernmentalists and various critics. More recently, the Commission's role has been examined in the context of EU's experience of crisis. The second debate relates to the Commission's influence as a policy entrepreneur, and the third 
to the Commission as an executive body. The fourth is normative and concerns the Commission in a wider discussion regarding the EU's democratic credentials.

The Commission and European Integration

The power of the Commission was first contested in a debate between the two "grand theories" of integration-neofunctionalism and intergovernmentalism-which dominated the EU literature from the 1950 s until the 1980 s and continues to remain relevant. Since the application to the EU of theories of delegation in the mid-1990s, however, the terms of the debate have changed.

\section{Neofunctionalism Versus Intergovernmentalism}

Neofunctionalism, originally based on the writings of Haas (1958) and Lindberg (1963), saw the European Commission as instrumental to European integration. The foundation of the Communities as a regional organization was the first step in a process that would become self-reinforcing. They posited "functional spillover" as a key mechanism: common action in one sector creates pressure to integrate other sectors. The demand for further integrating measures would come from domestic actors-elected officials, interest groups, and large firms who believed that their interests would be best satisfied at the regional level-but the European Commission would play a key role in promoting the transfer of loyalties to the EU level as the Communities proved more efficient than states in meeting welfare needs, goal articulation, advancing EU policies, and brokering negotiations with member states so as to "upgrade the common interest."

The idea that the Commission could play a leading role in bringing integration about was contested by intergovernmentalism, which drew heavily on the realist school in international relations. From this perspective, European integration was no different from intergovernmental cooperation elsewhere. States could be expected to cooperate for as long as it was beneficial. They retained control over decision-making as well as the pace, scope, and form of cooperation. Hoffmann (1966) argued that the authority of the Commission was limited in scope, conditional on member state approval, reversible, and likely to be confined to areas of "low politics." "High politics" could be expected to remain an exclusive preserve of national governments. 
The terms of the debate changed with the emergence of international regime theory in the late 1970s, which reconciled a state-centric conception of the international order with recognition that international institutions could carry out functional tasks that were beneficial to governments. However, even if he saw the EEC as an international regime, Hoffmann (1982) maintained his view that the EEC's institutions were weak "because they lack autonomy (from the member states) and because their capacity to act is small" (Hoffman, 1982, p. 32). Writing in the wake of the Single European Act (SEA), Moravcsik (1991) also rejected the idea that the Commission could play a central role. Contending that integration had proceeded through a sequence of intergovernmental bargains, Moravcsik contended that national governments were the key actors in his analysis of the SEA, the Treaty of European Union (Moravcsik, 1993), and his history of integration (1998). In a later article, Moravcsik (1999) argued that the Commission lacked the resources to exert independent influence.

Since the mid-1980s, authors have challenged intergovernmentalist claims that the Commission exerted only negligible influence in the Community's development on empirical grounds (see, e.g., Green Cowles, 1995; Ross, 1995; Sandholtz \& Zysman, 1989; Schmidt, 1996) and that it had no influence at intergovernmental conferences (IGCS) (Beach \& Christiansen, 2007). Some authors who had previously attributed minimal influence to the Commission recognized that it had played a role (Hoffman \& Keohane, 1992). There were also more systematic attempts to recast neofunctionalism. Notably, Stone Sweet and Sandholtz (1998) proposed a " modified neofunctionalism" that emphasized the Commission's capacity to mobilize transnational business and to sway national governments.

\section{Theories of Delegation and the Study of the Commission}

The application of insights from the theory of delegation that had been used to investigate the delegation of regulatory power from the legislative to the executive branch in the U.S. political system brought about a radical change in the study of the Commission. With the principal-agent model with which it is strongly associated, the theory of delegation was used 
mainly by critics of intergovernmentalism to demonstrate the Commission's capacity for independent action (Kassim \& Menon, 2003).

The functional theory of delegation holds that it may be beneficial for a "principal" to confer responsibilities to an "agent" in order to ensure that certain goals or objectives of the principal are realized. In the political world, a principal may decide to delegate for the following reasons:

- To overcome problems of collective action, where actors anticipate benefits from cooperation but want to ensure that the contract is respected by other parties

- To deal with the problem of "incomplete contracting," by empowering an agent to fill in the details of a framework agreement and adjudicate future disputes

- To reduce information asymmetries and improve the quality of policy in technical areas where an agent has specialist expertise

- To demonstrate the credibility of commitment

- To displace responsibility for unpopular decisions;

- To "lock in" distributional benefits that particular institutional arrangements are likely to deliver

- To resolve the problem of policymaking instability and thereby avoid the problem of policy "cycling" that besets systems of majoritarian decision-making (Riker, 1980) At the same time, delegation can lead to problems that the principal-agent model highlights. The agent benefits from asymmetric information, so can engage in opportunistic behavior-shirking - that is costly to the principal, but difficult to detect. The likelihood of shirking is increased by slippage, when the structure of delegation "provides incentives for the agent to behave in ways inimical to the preferences of the principal" (Pollack, 1997, p. 108).

The "principal's problem" (Ross, 1973) is to design control mechanisms that limit the possibilities for shirking, slippage, and drift, but that do not outweigh the benefits derived from delegation, and that allow the agent sufficient discretion in carrying out the delegated tasks. Here the literature distinguishes between monitoring strategies that are continuous, but costly - "police patrols" - and "fire alarms" that are discontinuous and less costly, but 
depend on the action of third parties. Principals can also impose sanctions, ex ante or ex post.

Writing from the perspective of rational choice institutionalism, Pollack (1996, 1997, 2003) pioneered the application of the approach to the EU. He argues first that the member states benefit from the delegation to the Commission of responsibility for policy initiation (agendasetting power), monitoring compliance and enforcing treaty provisions (guardian of the treaties), and incomplete contracting and regulatory power (executive responsibilities). He also evaluates the control mechanisms and sanctions available to the member states. He argues that comitology as a "police patrol" mechanism is effective, but costly, while "fire alarms" in the form of checks on the Commission's activities by other EU institutions work well. Sanctions, by contrast (budgetary costs, appointments and re-appointments, and new Council legislation) are not very effective. They are either too difficult to mobilize because they require a high level of agreement among the member states or, in the case of recontracting (i.e., revising the Commission's mandate), a nuclear option and therefore not credible.

Pollack concludes that the Commission's autonomy is shaped by four factors: the distribution of preferences among member states and the Commission; decision rules for applying sanctions, overruling legislation, and changing agents' mandates; incomplete information and uncertainty in the principal-agent relationship; and the presence of constituencies within the member states (subnational institutions, interest groups, or individuals), which can bypass member governments or place pressure on them. Other authors working within the same school (e.g., Tallberg, 2002, 2007) have used the theory of delegation and principal-agent to explain the delegation of responsibilities and powers to the Commission, as well as the Commission's capacity to influence decisionmaking. Franchino $(2002,2004)$, by contrast, uses the approach to explain the choices made by the Council in the delegation to the Commission in secondary legislation. Focusing on implementation powers, he finds that the variation in delegation and discretion depend on the level of conflict in Council, the decision rule in operation, the degree of conflict between Council and Commission, and the complexity of policy area. 
In his examination of the relationship between member governments and the Commission, written from the perspective of historical institutionalism, Pierson (1996) does not use the terminology of principal-agent, but does draw on its reasoning. Member governments, he argues, have strong incentives to delegate authority to the Commission. They may not intend the Commission to become autonomous, but for several reasons (the complexity of EU processes, asymmetric information that favors the Commission, interaction effects, change in member state preferences, and resistance on the part of the Commission)unintended consequences-it becomes increasingly difficult over time for them to maintain their control. With the sunk costs that national capitals have incurred, the rising price of exit they face, as well as the high institutional barriers to reform, it becomes increasingly difficult once gaps in control have emerged for them to assert themselves.

Finally, in their articulation of the multilevel governance approach, Marks, Hooghe, and Blank (1996) refer to the theory of delegation and use the language of principal-agent to emphasize that the state-centric view of the EU is outdated. In their critique of intergovernmentalism, the authors highlight the difficulty faced by multiple principals with differing preferences, impediments to coherent principal action, informational asymmetries between principals and agents, and the unintended consequences of institutional change as important constraints on the ability of national governments to maintain control over the Commission.

\section{The European Commission, the Eurozone Crisis and Beyond}

The most recent iteration of the debate on the Commission's role in European integration relates to the prolonged period of crisis experienced by the EU since the results of referendums on treaty reform in the Netherlands and France in 2005. The rejection of the Constitutional Treaty by votes in two of the six founder member states was followed by overlapping crises concerning sovereign debt in the eurozone, the influx of refugees displaced by conflict on the Union's periphery, the rise of Eurosceptic populism, including Brexit, the emergence of illiberal democracy within the EU, and new and renewed geopolitical threats. In terms which have often echoed the earlier clash between intergovernmentalist and supranationalist accounts of integration, scholars have sought to 
examine which EU institution took the lead role in determining the EU's response and assess the impact of the crisis on the powers and authority of the respective institutions.

After an initial focus on the European Council (see, e.g., Bickerton, Hodson, \& Puetter, 2015; Bressanelli \& Chelotti, 2016; De Schoutheete, 2012; Fabbrini, 2015; Puetter, 2014), which it was thought, because of the seniority of its membership, was the only institution that had the authority to address issues of such magnitude, authors have highlighted the influence of supranational factors, including agency on the part of the European Commission and, in the case of the eurozone crisis, the Central European Bank (Carstensen \& Schmidt, 2018; Dehousse, 2016; Kassim \& Tholoniat, 2020; Schimmelfennig, 2018). A number have argued that, despite the importance, even centrality, of the European Council, the European Commission has emerged as a "winner" of the crisis (Bauer \& Becker, 2014).

Discussion of the crises has also prompted extended reflection on the EU's longer-term development and the changing institutional balance. Particularly influential in this regard has been the work of Fabbrini and Puetter (2016). Reviewing the EU's evolution since the Maastricht Treaty, they highlight the continued preparedness of the member states, on the one hand, to expand competencies into new and sensitive areas of what Hoffmann one called "high politics," notably foreign and security policy, justice and home affairs, and macroeconomic policy. On the other hand, they note that delegation has been contingent on reserving decision-making power to intergovernmental forums-either the Council of the European Union or the European Council. There have been few instances of a willingness to extend to replicate the Commission's role in policy initiation in these new fields. As a result, although the "Community method," in which the Commission plays a pivotal role, survives in relation to the common market, a new mode of intergovernmentalism has been created in areas added since Maastricht. The result is a system of dual governance.

\section{The Commission as Policy Entrepreneur}

In the wake of the SEA, with its emergence as an authoritative decision-making arena in many areas of economist activity, the EU came increasingly to be conceptualized as a polity rather than an international organization. With a more detailed focus on the policy process, the impact of new legislative procedures and decision rules, and the Commission's reinvigorated role, scholars directed their attention to the Commission's resources and 
assessing its influence on the EU's decisional outputs within a complex institutional setting. In their analyses, they applied theories, models, and concepts from comparative politics and public policy (Hix, 1994, though see Hurrell \& Menon, 1996).

In the early 1990s, a number of path-breaking empirical studies examined policy development at the sector level and revealed the extent to which the Commission had acted as a policy entrepreneur. Scholars drew attention to the Commission's resources as a "process manager" (Eichener, 1992), underlined the informational advantages it possessed (Marks et al., 1996), and offered insights into the Commission's modus operandi as a "purposeful opportunist" (Cram, 1993). They also highlighted the influence exercised by the Commission exercise in virtue of its ability to propose and frame legislation, set the policy agenda, and shape to a high degree the content of final text adopted by the Council. The Single European Act and the 1992 project also generated a theoretical debate about the respective influence of the main EU institutions in the legislative process. Pollack's conceptualization of the European Commission as an agenda setter was an important, pioneering contribution. In her seminal 2000 article, Susanne Schmidt showed that the Commission's influence derived not only from its ability to decide which proposals to put on the table and when, but from its special prerogatives in competition policy and its right under the treaties to initiate legal action in order to ensure that actors, public and private, complied with their obligations under EU law.

Schmidt identified two specific strategies available to the Commission to overcome member state reluctance or opposition in the Council, and thereby to ensure legislative action on the part of the EU. The Commission could "divide and conquer" by transforming the policy preferences of states opposed to liberalization by using its competition policy prerogatives to force domestic change in those countries, thereby exposing them to the danger of being disadvantaged if they failed to acquiesce; or it could use the threat of litigation to confront reluctant member states with a choice between the "lesser evil" of controlled reform or the unpredictable path of legislation by judicial fiat.

More generally, as the legislative procedures of the EU have developed and redistributed power among key actors, scholars have sought to measure and assess the influence of EU 
institutions. The main interest has lain in evaluating the impact of procedural reforms introduced by successive treaty changes, particularly on the European Parliament, and especially the European Parliament vis-à-vis the Council of the European Union. The landmark work was undertaken by Crombez $(1996,1997)$ and by Tsebelis alone $(1994)$ or with co-authors (Tsebelis \& Garrett, 1997, 2000). The spatial models developed by these authors focused mainly on the European Parliament and the conditions under which it could exert influence over legislation. Despite the preoccupation with "bicameral politics" in the "EU's legislature," the Commission's (conditional) agenda-setting power also featured in these models.

More recently, legislative specialists have directed their attention to the Commission's influence, and specifically how the Commission has been affected by changes to co-decision. The consensus among these scholars is that the Commission's power has been significantly diminished, particularly as a consequence of the growing number of agreements between the European Parliament and the Council of the European Union at first reading (Burns, 2004; Costello \& Thomsen, 2013; Reh, Héritier, Bressanelli, \& Koop, 2011). Gardner (2013), meanwhile, has explored how the Commission's use of its ability to withdraw proposals also allows it to shape the EU's policy agenda.

An important sub-literature has also developed on the pre-legislative phase of law making. The relationship between the Commission and interest groups and other lobbyists has always attracted scholarly interest, but recently authors have taken a new and more sophisticated approach to the interaction. While Dür, Bernhagen, and Marshall (2015) have examined whether some types of interest group are more successful than others, van Ballaert (2017) has approached the relationship from the side of the Commission and investigated what factors account for the selection of consultation procedures it uses.

\section{The Commission as an Executive}

In the understanding of the EU as a polity, the Commission has come routinely to be conceptualized as part of the EU's executive. Despite broad agreement that executive functions in the EU are shared between EU-level institutions on the one hand (though see Majone, 2002a), and the member states, who are responsible for the implementation of 
policy through their national administrations (Kassim, 2014), on the other, debate continues as to which EU institutions - other than the Commission and EU agencies-make up the EU component of the executive (see Kreppel, 2011; Tallberg, 2007). Irrespective of how that question is answered, the executive frame usefully highlights the Commission's interaction with other actors in its management and implementation roles.

\section{Comitology}

In the EU, as in other political systems, the legislature routinely delegates responsibility for detailing how individual items of legislation are to be implemented to the executive. In the EU's case, committees composed of representatives from the member states, with varying powers, exercise oversight over the Commission as it carries out this responsibility. This comitology system has its origins in the common agricultural policy from which it expanded ad hoc into other areas. It was standardized following the SEA by a Council decision in July 1987 , reformed by the same in June 1999, then again in July 2006, and overhauled following the Lisbon Treaty by a Regulation of the Council and Parliament in 2011 (European Parliament and Council of the European Union, 2011).

As well as granting the European Parliament-a long-term critic of comitology-a general right to receive information about committee decisions and to scrutinize proposed measures for ultra vires, the new system introduced a major simplification by reducing the number of committee procedures from four to two. Under the examination procedure, which is intended for measures with broad scope and potentially far-reaching impact, the Commission's proposed measure can be rejected by a qualified majority against (negative vote) or adopted where a qualified majority is in favor of the Commission's proposed measure (positive vote). Where there is no qualified majority either way, the Commission can decide whether to implement the proposed measure or submit a new version to the committee. Under the advisory procedure, the Commission can decide whether or not to implement the proposed measure, but must take "utmost account" of the committee's opinion.

Scholars have focused on the positions taken by the Commission and Council over which procedure should be included. Dogan (1997, 2002 found that the institutions did not 
necessarily support procedures that strengthened their hand. For example, despite protestations by the Commission about the Council's reluctance to accept the advisory procedure, the Council agreed to its adoption under 40 Commission proposals between 1987 and 1995. However, Hix and Høyland (2011) suggest that this may reflect that the Commission only proposes the advisory procedure when it thinks the Council might accept. Comitology has also been cited as an example of non-hierarchical and deliberative policy style (Joerges \& Neyer, 1997) in the face of intergovernmentalist claims that interaction between national representatives takes the form of hard bargaining.

\section{EU Agencies}

The emergence and proliferation of EU agencies-from 2 to more than 40 between 1990 and 2015-was a development to which the Commission was initially opposed, first, because it was concerned about the dispersal of power and resources, and second, because it believed that the principle that the treaty had reserved executive responsibilities to the Commission alone had been supported by the Court of Justice of the European Union-the so-called "Meroni doctrine." However, by the time of the Prodi Commission (1999-2004), the Commission had come to recognize the benefits that EU agencies afforded-the high profile generated by the tasks assigned to them, their technical knowledge, their role in pooling national and European expertise, and their relieving the Commission of administrative tasks, so allowing it to concentrate on political decisions.

Although the literature has been mainly preoccupied with the origins of agencies (see, e.g., Barbieri \& Ongaro, 2008; Busuioc, Groenleer, \& Trondal, 2012; Dehousse, 1997; Kreher, 1997; Verhoest, van Thiel, Bouckaert, \& Laegreid, 2012), some authors have examined the relationship between EU agencies and the Commission. It had been assumed that agencies would be self-interested, hostile to the Commission, and unlikely to cooperate. Egeberg and Trondal (2011) sought to test this view empirically. They found from responses to surveys that they administered within EU agencies that staff consider the Commission a partner and an ally rather than a rival. 


\section{National Administrations, Agencies, and Networks}

The EU's reliance on national bodies for the coherent and effective implementation of EU legislation presents the Commission with a formidable challenge. Although the Commission has overall responsibility for the enforcement of EU rules, its small size and distance from the front line impose significant constraints. Particularly since the SEA-a watershed moment, as the single internal market could not be achieved if the uneven implementation of legislation were allowed to create barriers to trade, but where the Commission was largely untested (Metcalfe, 1992) -the Commission has pursued at least four strategies.

First, prioritizing the single market as an area of action, the Commission has used a variety of techniques to achieve high levels of implementation. As well as a series of action plans to highlight particular areas, it has set year-on-year targets and uses a biannual scoreboard to publicize the successes of some member states and to name and shame the laggards. The strategy has succeeded in meeting the $0.5 \%$ implementation deficit target.

Second, the Commission has sought to delegate non-core functions to EU agencies on a programmatic basis. An important element has been to bring coherence and accountability to the operation of agencies. Agencies had been created for different purposes and varied in responsibility, size, and organization (European Commission, 2008), and their proliferation had been disorderly and uncontrolled. In an initiative launched in 2008, the Commission sought to increase its effectiveness. Further measures followed in 2012 and 2013, including a 2013 communication that set out the staffing level and subsidy of each decentralized agency under the multiannual financial framework (MFF) 2014-2020.

Third, Commission departments have formed close relations with the sectoral and subsector networks that bring together national regulatory agencies. This has been the case, for example, in broadcasting, with the European Platform of Regulatory Authorities; in energy, the European Regulators Group for Electricity and Gas; in financial services, with the Committee of European Securities Regulators, the Committee of European Insurance and Occupational Pensions' Supervisors, and the Committee of European Banking Supervisors (Coen \& Thatcher, 2008; Thatcher \& Coen, 2008). Some of these networks have now been superseded by network agencies. 
Fourth, the Commission has sought to create networks between public authorities. Examples include SOLVIT, formed in 2002, to link national authorities and thereby ensure that the benefits of the single market can be directly enjoyed by consumers across the EU, and the Internal Market Information (IMI) system, which enables national authorities in the member states to exchange information. Although they have their limitations, these networks have provided an important infrastructural underpinning for the single market.

These initiatives have been assisted by recognition of the benefits of cooperation on the part of actors at national and EU level. Studies conducted by Egeberg and Trondal (2009) and Ongaro, Barbieri, Belle, and Fedele (2015) show that national agencies view the Commission as a partner, not a rival. Second, national governments or departments and agencies at the sectoral or sub-sectoral level have responded to incentives to make the single market work. Similarly, Heidbreder (2014) has mapped the formation and operation of horizontal networks involving national actors in three areas of the single market. The scope for institutional autonomy is perhaps diminishing.

In some areas, however, the EU has resorted to legislation to improve enforcement. Although member states have a duty to enforce EU rules, compliance and enforcement is sometime uneven. In energy, telecommunications, and competition policy, EU legislation includes the requirement that national authorities are appropriately resourced to carry out their responsibilities (Verhoest et al., 2012). This is the closest to "managing by design" (Metcalfe \& Richards, 1990) that the Commission has been able to achieve.

\section{The Commission as Part of a Wider Executive}

Some scholars have been keen to look beyond the functions and capacities of the Commission as an executive body and have contemplated the Commission as part of a new multilevel executive entity that has emerged since the creation of the single internal market. The participants in this debate highlight the linkages between the Commission and national bodies, and argue that there has been a transformation of public administration within the EU. The idea of a "fused administration" (Wessels, 1997), which emphasizes the close interaction between the Commission and member state bureaucracies, was perhaps 
the first conceptualization intended to highlight the emergence of a new executive order and to convey its permanence.

Although its influence has persisted, "fusion" has been challenged by several other conceptualizations. Most highlight the transformation of national administration as a result of agencification and the links that have developed between the Commission and those new bodies. Trondal (2010), for example, has argued that an "emergent European executive order" has grown up around the Commission, with a parallel administration of EU-level agencies and EU committees.

The same relationship is emphasized in the notion of a multilevel administration, proposed by Egeberg (2006b). According to the synoposis for the latter volume:

The executive branch of government in Europe is being transformed in a profound way. We are witnessing the development of EU-level executive bodies that, for the first time in the history of international organizations, are capable of acting relatively independently of member-state governments and councils of ministers. As a consequence, the quite peculiar development of the Commission and EU agencies seems to trigger significant centrifugal forces within national governments. National agencies are developing into components of two administrations: they continue to serve national ministries but also take part in the formulation and implementation of EU policies in close cooperation with the Commission or EU-level agencies, with relative independence from their respective ministries. The authors ... argue that a genuine Union administration that spans levels of governance is definitely in the process of development.

The articulation in the form of a post-Westphalian order, as outlined by Curtin and Egeberg (2008), is important also for its normative dimension, as it asserts that effective controls can no longer be exercised at either the national or the EU level:

With the advent of the European Union and its predecessors, Europe's executive order has become qualitatively different from the intergovernmental order inherited from the past. We ascribe this phenomenon in particular to the consolidation of the European Commission as a new and distinctive executive centre at the European level. This institutional innovation triggers significant centrifugal forces within national governments due to the Commission's 
strategy of establishing direct partnerships with semi-independent national agencies that are crucial for the implementation as well as the formulation of EU policies. The new order does not replace former orders; instead it tends to be layered around already existing orders so that the result is an increasingly compound and accumulated executive order. (Curtin \& Egeberg, 2008, p. 639)

Finally, the characterization offered by Hofmann and Turk (2007) is perhaps the most radical. They deny the existence of any territorial differentiation or layering. Rather, they insist that

the EU is characterized by its multilevel cooperative governance structures. They are designed to include the different decision-making levels and generate knowledge in the administrative system prior to taking decisions. This has resulted in the emergence of what can be described as a European "integrated administration." (Hofmann \& Turk, 2007, p. X)

\section{The Commission and the EU's Democratic Credentials}

The Commission features in many, though not all, discussions of the EU's alleged "democratic deficit." The main questions concern the Commission's remoteness and purported lack of democratic accountability, though some criticisms are based on an exaggerated view of its power and influence, misunderstandings of its role within the wider EU system, or misrepresentation of its independence. In practice, the Commission only has final decision-making authority in competition policy. Elsewhere, it has the ability to propose, but decisions are taken by one or more other bodies, usually the Council and the European Parliament.

More broadly, as Christiansen (1997) observed more than two decades' ago, the Commission is "multiply accountable," from its appointment by the European Council and approval by the European Parliament, to the possibility of its removal by a censure vote in the European Parliament, oversight of its implementing activities through comitology, and scrutiny of its financial management by the European Court of Auditors and the European Parliament. Regular reporting to Parliament and the Council; undertaking action at the behest of the European Council; scrutiny by the media and interest groups; and regulation 
of its financial management processes and budgetary control through legislative acts, adopted by the Council and Parliament, are further mechanisms.

The Commission has featured explicitly in two accounts that suggest that there is no democratic deficit - the first, a view associated with Jean Monnet that European integration is an essentially technocratic process, led by a small body of experts who, in contrast to selfserving politicians, will act to advance the long-term welfare of European citizens (Featherstone, 1994); and the second, Majone $(1994,1996)$ 's conceptualization of the EU as a "regulatory state," where the expert staff of non-majoritarian (i.e., unelected) bodies will implement efficient policies that advance the common good.

Follesdal and Hix (2005) and Hix (2008) meanwhile contend that a democratic deficit does exist in the EU because European citizens do not have the opportunity to "throw the rascals out." Because political contestation and an electoral link between citizens or their representatives and decision-makers are minimal conditions for democracy, they propose that the Commission president should be elected by national parliaments or nominated by the European Parliament. Yet, as well as the concern expressed by Majone (2002b) that partisanalizing the Commission president reduces the legitimacy of the Commission because the Commission would be identified with a faction or coalition, it is not at all clear, as the Spitzenkandidaten process has demonstrated, that an electoral contest is sufficient to mobilize EU citizens, increase citizen awareness of EU politics, or encourage domestic political contestation about EU policy.

A different approach is taken by Murdoch et al. (2016), who examine the Commission as a representative bureaucracy. They focus on the composition of the Commission by nationality and compare the beliefs and values of member state nationals in the Commission staff with public opinion in their home states. Their analysis reveals an alignment of views, which challenges the contention that the Commission is a rootless elite whose staff members are out of touch with their compatriots. 


\section{Conclusion}

The European Commission is the institution that is most closely identified with and symbolizes the European Union. Whether or not it is in decline, the Commission's responsibilities, its hybrid structure, and its influence within the EU system and beyond have ensured that that organization continues both to attract attention and to divide opinion more than five decades after its inception. The functions bestowed on it under the treaties ensure that the Commission's continuous involvement in virtually all EU activities, the interaction between the College and the services, and the relationship between the Commission president and the other members of the Commission are recast with each new administration, and the Commission's power has fluctuated with the changing interinstitutional balance.

These properties and the changeability of the environment within which it operates make the Commission a fascinating institution. Yet, at the same time, they make it a challenging, and sometimes elusive, subject of study. As a result, many misleading accepted wisdoms and myths about the Commission and the people who work for it continue to circulate in political debate, public discussion, and scholarship.

This leads to three reflections. First, although theorizing about the Commission is important-indeed, essential-assumptions, claims, and hypotheses about the organization need constant empirical testing. Second, the breadth, scope, and varied character of the Commission's activities and responsibilities suggest a need for caution in generalizing about its power and influence. Too often in the literature claims are based on a handful of case studies or a very small sample. Third, a continual effort of monitoring and investigation is essential, given the Commission's importance, but also the complexity of the Commission and the wider EU system. 


\section{References}

Abélès, M., Bellier, I., \& McDonald, M. (1993). An anthropological approach to the European Commission. (Unpublished report). HAL: Archive ouverte en Sciences de l'Homme et de la Société.

Alayrac, P., Connolly, S, \& Kassim, H. (2019) 'Research Briefing 3: Careers, career-building and mobility in the European Commission', available for download at https://www.uea.ac.uk/documents/241631/0/Briefing+3+Careers+career+building+an d+mobility+final.pdf/6c84ba6b-4195-d018-77a4-ff89d0fa499b.

Ban, C. (2013). From diversity to unity: Management and culture in an enlarged European Commission. Basingstoke, U.K.: Palgrave Macmillan.

Barbieri, D., \& Ongaro, E. (2008). EU agencies: What is common and what is distinctive compared with national-level public agencies. International Review of Administrative Sciences, 74(3), 395-420.

Bauer, M. W. (2008a). Diffuse anxieties, deprived entrepreneurs: Commission reform and middle management. Journal of European Public Policy, 15(5), 691-707.

Bauer, M. W. (2008b). Special issue: Reforming the European Commission. Journal of European Public Policy, 15(5), 625-626.

Bauer, M. W., \& Becker, S. (2014). The unexpected winner of the crisis: The European Commission's strengthened role in economic governance. Journal of European Integration, 36(3), 213-229.

Bauer, M. W., \& Knill, C. (2016). Policy-making by international public administrations: Concepts, causes, and consequences. Journal of European Public Policy, 23(7), 949959.

Beach, D., \& Christiansen, T. (2007). Introduction: Political agency in the constitutional politics of the European Union. Journal of European Public Policy, 14(8), 1163-1166.

Bickerton, C., Hodson, D., \& Puetter, U. (2015) The New Intergovernmentalism: States and Supranational Actors in the Post-Maastricht Era, Oxford University Press.

Bressanelli, E., \& Chelotti, N. (2016). The shadow of the European Council. understanding legislation on economic governance. Journal of European Integration, 38(5), 511-525.

Bulmer, S., \& Wessels, W. (1987). The European Council: Decision-making in European politics. Basingstoke, U.K.: Palgrave. 
Burns, C. (2004). Codecision and the European Commission: A study of declining influence? Journal of European Public Policy, 11(1), 1-18.

Busuioc, M. Groenleer, M., \& Trondal, J. (Eds.). (2012). The agency phenomenon in the European Union ... Manchester, U.K.: Manchester University Press.

Campbell, J. (1983). Roy Jenkins: A biography. London, U.K.: Weidenfeld \& Nicolson.

Carstensen, M. B., \& Schmidt, V.A. (2018). Power and changing modes of governance in the euro crisis. Governance, 31(4), 609-624.

Chamon, M. (2016) EU Agencies: Legal and Political Limits to the Transformation of the EU Administration, Oxford University Press

Christiansen, T. (1997). Tensions of European governance: Politicised bureaucracy and multiple accountability in the European Commission. Journal of European Public Policy, 4(1), 73-90.

Christiansen, T. (2016). After the Spitzenkandidaten: Fundamental change in the EU's political system? West European Politics, 39(5), 992-1010.

Cini, M. (1996). The European Commission: Leadership, organisation, and culture in the EU administration. Manchester, U.K.: Manchester University Press.

Coen, D., \& Thatcher, M. (2008). Network governance and multi-level delegation: European networks of regulatory agencies. Journal of Public Policy, 28(1), 49-71.

Connolly, S., \& Kassim, H. (2015a). The European Commission. Facing the future. Norwich, U.K.: University of East Anglia.

Connolly, S., \& Kassim, H. (2015b). The permanent Commission bureaucrat. In M. W. Bauer \& J. Trondal (Eds.), Palgrave handbook of the European administrative system (pp. 161-187). Basingstoke, U.K.: Palgrave Macmillan.

Connolly, S. and Kassim, H. (2019) Research Briefing 2: 'An administration of lawyers'?, available for download at https://www.uea.ac.uk/documents/241631/0/Briefing+2+An+administration+of+lawy ers+final.pdf/37299aa2-a656-210c-ea13-329094241602, checked 2 March 2020

Coombes, D. (1970). Politics and bureaucracy in the European Community: A Portrait of the Commission of the E.E.C. London, U.K.: Allen \& Unwin.

Costello, R., \& Thomson, R. (2013). The distribution of power among EU institutions: Who wins under codecision and why? Journal of European Public Policy, 20(7), 1025-1039. 
Cram, L. (1993). Calling the tune without paying the piper? Social policy regulation: The role of the Commission in European Community social policy. Policy and Politics, 21(2), $135-146$.

Cram, L. (1994). The European Commission as a multi-organization: Social policy and IT policy in the EU. Journal of European Public Policy, 1(2), 195-217.

Crombez, C. (1996). Legislative procedures in the European Community. British Journal of Political Science, 26(2), 199-228.

Crombez, C. (1997). The co-decision procedure in the European Union. Legislative Studies Quarterly, 22(1), 97-119.

Curtin, D., \& Egeberg, M. (2008). Tradition and innovation: Europe's accumulated executive order. West European Politics, 31(4), 639-661.

Deckarm, R. (2017). From national enclaves to supporting offices: An analysis of the 1999 reform of European Commissioners' cabinets. Journal of Contemporary European Research, 12(3), 734-753.

Dehousse, R. (1997). Regulation by networks in the European Community: The role of European agencies. Journal of European Public Policy, 4(2), 246-261.

Delors, J. (2004). Mémoires. Paris, France: Plon.

de Schoutheete, P. (2012). The European Council. In J. Peterson, \& M. Shackleton (eds.), The Institutions of the European Union, Oxford University Press, 3rd ed., pp. 43-67

Dimitrakopoulos, D. G. (Ed.). (2004). The changing European Commission. Manchester, U.K.: Manchester University Press.

Dimitrakopoulos and Kassim 2005; Reference should be Dimitrakopoulos, D.G. and Kassim, H. (2005) 'La Commission européenne et le débat sur l'avenir de l'Europe', Critique international, 29(4), 169-90.

Dogan, R. (1997). Comitology: Little procedures with big implications. West European Politics, 20(3), 31-60.

Dogan, R. (2000) 'A Cross-Sectoral View of Comitology: Incidence, Issues and Implications' in T. Christiansen \& E. Kirchner (eds) Committee Governance in the European Union, Manchester University Press, pp. 45-61.

Donnelly, M., \& Ritchie, E. (1997). The College of Commissioners and their cabinet. In G. Edwards \& D. Spence (Eds.), The European Commission (2nd ed., pp. 33-67). London, U.K.: Cartermill. 
Drake, H. (2000) Jacques Delors: Perspectives on a European Leader, Routledge

Dumoulin, M. (Ed). (2007). The European Commission, 1958-72: History and memories. Luxembourg: Office for Official Publications of the European Communities.

Dür, A., Bernhagen, P., \& Marshall, D. (2015). Interest group success in the European Union: When (and why) does business lose? Comparative Political Studies, 48(8), 951-983.

Egeberg, M. (2006a). Executive politics as usual: Role behaviour and conflict dimensions in the College of European Commissioners. Journal of European Public Policy, 13(1), 115.

Egeberg, M. (Ed.). (2006b). Multilevel union administration. Basingstoke, U.K.: Palgrave Macmillan.

Egeberg, M., \& Heskestad, A. (2010). The denationalization of cabinets in the European Commission. Journal of Common Market Studies, 48(4), 775-786.

Egeberg, M., \& Trondal, J. (2009). National agencies in the European administrative space: Government driven, Commission driven, or networked? Public Administration, 87(4), 779-790.

Egeberg, M., \& Trondal, J. (2011). EU-level agencies: New executive centre formation or vehicles for national control? Journal of European Public Policy, 18(6), 868-887.

Egeberg \& Trondal. (2014). From p. 37.

Eichener, V. (1992). Social dumping or innovative regulation? Processes and outcomes of European decision-making in the sector of health and safety at work regulation. Working Paper SPS 92/28. Florence, Italy: European University Institute.

Ellinas, A. A., \& Suleiman, E. (2012). The European Commission and bureaucratic autonomy: Europe's custodians. Cambridge, U.K.: Cambridge University Press.

Endo, K. (1999). The presidency of the European Commission under Jacques Delors: The politics of shared leadership. Basingstoke, U.K.: Palgrave Macmillan.

European Commission (2008); European Commission (2008) 'European agencies - The way forward', Communication from the Commission to the European Parliament and the Council, $\operatorname{COM(2008)} 135$ final, Brussels, 11.3.2008

European Commission. (2018). Report from the Commission to the European Parliament and the Council pursuant to Article 27 of the Staff Regulations of Officials and to Article 12 of the Conditions of Employment of Other Servants of the European Union (Geographical balance). Brussels, 24.8.2018 COM(2018) 377 final/2. 
European Commission. (2019). Human resources. Key figures. Staff members.

European Parliament and Council of the European Union. (2011). Regulation (EU) No 182/2011 of the European Parliament and of the Council of 16 February 2011 laying down the rules and general principles concerning mechanisms for control by Member States of the Commission's exercise of implementing powers. Eur-Lex.

European Court of Auditors (2019) Special report no 15/2019: Implementation of the 2014 staff reform package at the Commission-Big savings but not without consequences for staff.

Fabbrini, S. (2015). Which European Union? Europe after the euro-crisis. Cambridge, U.K.: Cambridge University Press.

Fabbrini, S., \& Puetter, U. (2016). Integration without supranationalisation: Studying the lead roles of the European Council and the Council in post-Lisbon EU politics. Journal of European Integration, 38(5), 481-495.

Featherstone, K. (1994). Jean Monnet and the "democratic deficit" in the European Union. Journal of Common Market Studies, 32(2), 149-170.

Follesdal, A., \& Hix, S. (2005). Why there is a democratic deficit in the EU: A response to Majone and Moravcsik. European Governance Papers (EUROGOV) No C-05-02.

Franchino, F. (2002). Efficiency or credibility? Testing the two logics of delegation to the European Commission. Journal of European Public Policy, 9(5), 677-694.

Franchino, F. (2004). Delegating powers in the European Community. British Journal of Political Science, 34(2), 449-476.

Gardner, J. (2013). Agenda-setting through the backdoor? The Commission's use of its power to withdraw. Journal of Politics \& International Studies, 9, 562-1317.

Georgakakis, D. (2012). Le champ de l'Eurocratie, Une sociologie du personnel de l'UE. Paris, France: Economica.

Georgakakis, D. (2017). European civil service in (times of) crisis: A political sociology of the changing power of Eurocrats. Basingstoke, U.K.: Palgrave Macmillan.

Grant, C. (1994) Delors: Inside The House That Jack: Inside the House That Jacques Built, Nicholas Brealey Publishing

Green Cowles, M. (1995). Setting the agenda for a new Europe: The ERT and EC 1992. Journal of Common Market Studies, 33(4), 501-526.

Haas, E. B. (1958). The uniting of Europe. Stanford, CA: Stanford University Press. 
Hallstein, W. (1965). The EEC Commission: A new factor in international life. International and Comparative Law Quarterly, 14(3), 727-741.

Hallstein, W. (1972) Europe in the Making, Allen and Unwin

Hartlapp, M., Metz, J., \& Rauh, C. (2014). Which policy for Europe? Power and conflict inside the European Commission. Oxford, U.K.: Oxford University Press

Heidbreder, E. (2014). Regulating capacity building by stealth: Pattern and extent of EU involvement in public administration. In P. Genschel \& M. Jachtenfuchs (Eds.), Beyond the regulatory polity? The European integration of core state powers (pp. 145-165). Oxford, U.K.: Oxford University Press.

Hix, S. (1994). The study of the European Community: The challenge to comparative politics. West European Politics, 17(1), 1-30.

Hix, S. (2008) What's Wrong with the Europe Union and How to Fix It, Polity

Hix, S., \& Høyland, B. (2011). The political system of the European Union. Basingstoke, U.K.: Palgrave Macmillan.

Hoffmann, S. (1966). Obstinate or obsolete? The fate of the nation state and the case of Western Europe. Daedalus, 95(3), 892-908.

Hoffmann, S. (1982). Reflections on the state in Western Europe today. Journal of Common Market Studies, 21, 21-37.

Hofmann, H. C. H., \& Turk, A. (2007). The development of integrated administration in the EU and its consequences. European Law Journal, 13(2), 253-271.

Hooghe, L. (2001). The European Commission and the integration of Europe. Cambridge, U.K.: Cambridge University Press.

Hooghe, L. (2005). Several roads lead to international norms, but few via international socialization: A case study of the European Commission. International Organization, 59(4), 861-898.

Hooghe, L. (2012) 'Images of Europe: How Commission Officials Conceive Their Institution's Role', JCMS: Journal of Common Market Studies, 50(1): 87-111. doi:10.1111/j.14685965.2011.02210.x

Hurrell, A., \& Menon, A. (1996). Politics like any other? Comparative politics, international relations and the study of the EU. West European Politics, 19(2), 386-402.

Joana, J., \& Smith, A. (2002). Les Commissaires Européens: Technocrates, Diplomates ou Politiques? Paris, France: Presses de Sciences Po. 
Joana, J., \& Smith, A. (2004). The politics of collegiality: The non-portfolio dimension. In A. Smith (Ed.), Politics and the European Commission: Actors, interdependence, legitimacy (pp. 30-46). London, U.K.: Routledge.

Joerges, C., \& Neyer, J. (1997) 'From Intergovernmental Bargaining to Deliberative Political Process: The Constitutionalisation of Comitology', European Law Journal, 3, 273-299. Johnston, M. T. (1994) The European Council: Gatekeeper of the European Community. Boulder, CO: Westview Press.

Juncker, J.-C. (2014, July 15). A new start for Europe: My agenda for jobs, growth, fairness and democratic change. political guidelines for the next European Commission. Strasbourg, Germany.

Kassim, H. (2004a). A historic accomplishment? The Prodi Commission and administrative reform. In D. G. Dimitrakopoulos (Ed.), The changing European Commission, Manchester, U.K.: Manchester University Press.

Kassim, H. (2004b). The Kinnock reforms in perspective: Why reforming the Commission is an heroic, but thankless, task. Public Policy and Administration, 19(3), 25-41.

Kassim, H. (2006) .The Secretariat General of the European Commission. In D. Spence with G. Edwards (Eds.), The European Commission (3rd ed.). London, U.K.: John Harper. Kassim, H. (2008). "Mission impossible," but mission accomplished: The Kinnock reforms and the European Commission. Journal of European Public Policy, 15(5), 648-668.

Kassim, H. (2012). The presidents and presidency of the European Commission. In E. Jones, A. Menon, \& S. Weatherill (Eds.), The Oxford handbook of the EU. Oxford, U.K.: Oxford University Press.

Kassim, H. (2014) L'administration européenne' in Renaud Dehousse (ed) (2014) L' Union européenne Collection Les Notices 3ème edition, La Documentation Française

Kassim, H. (2017). What's new? A first appraisal of the Juncker Commission" European Political Science, 16(1), 14-33.

Kassim, H., Connolly, S., Laffan, B., \& Bocquillon, P. (2019). The Juncker Commission: A new model of presidentialism? A core executive approach. Paper presented the 2019 EUSA International Biennial Conference, Denver, CO, May 9-11.

Kassim, H., \& Laffan, B. (2019) The Juncker presidency: The "political commission" in practice. Journal of Common Market Studies, 57(S1), 49-61. 
Kassim, H., \& Menon, A. (2003). The principal-agent approach and the study of the European Union: Promise unfulfilled? Journal of European Public Policy, 10(1), 121139.

Kassim, H., \& Menon, A. (2010). Bringing the member states back in: The supranational orthodoxy, member state resurgence and the decline of the European Commission since the 1990s. Paper presented at ECPR Fifth Pan-European Conference in Porto, Portugal, June 23-26.

Kassim, H., Peterson, J., Bauer, M. W., Connolly, S., Dehousse, R., Hooghe, L., \& Thompson, A. (2013) The European Commission of the twenty-first century. Oxford, U.K.: Oxford University Press.

Kassim, S. C., Dehousse, R., Rozenberg, O., \& Benjaballah, S. (2016). Managing the house: The presidency, agenda control and policy activism in the European Commission. Journal of European Public Policy, 24(5), 653-674.

Keohane, R. O., \& Hoffmann, S. (1991). Institutional change in Europe in the 1980s. In R. O. Keohane \& S. Hoffmann (Eds.), The new European Community: Decision-making and institutional change (pp. 1-39). Boulder, CO: Westview Press.

Kreher, A. (1997) 'Agencies in the European Community - a step towards administrative integration in Europe', Journal of European Public Policy, 4(2): 225-

245, DOI: $10.1080 / 13501769709696340$

Kreppel, A. (2011). Governing with a Janus face: National interests and ideology in the Council of Ministers. Paper presented at the DEUBAL workshop in Leiden, Netherlands, April 11.

Laursen, F. (2019). The Merger Treaty: Creating a single commission and council of the European communities. Oxford research encyclopedia of politics. Oxford, U.K.: Oxford University Press.

Lequesne, C. (1996). La Commission européenne entre autonomie et dépendance. Revue française de science politique, 46(3), 389-408.

Levy, R. P. (2004). Between rhetoric and reality: Implementing management reform in the European Commission. International Journal of Public Sector Management, 17(2), $166-177$.

Lindberg, L. N. (1963). The political dynamics of European economic integration. Stanford, CA: Stanford University Press. 
Ludlow, P. (2016). Roy Jenkins and the European Commission presidency, 1976-1980, Basingstoke, U.K.: Palgrave Macmillan.

Majone, G. (1994). The rise of the regulatory state in Europe. West European Politics, 17(3), 77-101.

Majone, G. (1996). Regulating Europe. London, U.K.: Routledge.

Majone, G. (2002a). Delegation of regulatory powers in a mixed polity. European Law Journal, 8(3), 319-339.

Majone, G. (2002b). The European Commission: The limits of centralization and the perils of parliamentarization. Governance, 15(3), 375-392.

Marks, G., Hooghe, L., \& Blank, K. (1996). European integration from the 1980s: Statecentric v. multi-level governance. Journal of Common Market Studies, 34(3), 341-378.

Metcalfe, L. (1992). After 1992: Can the Commission manage Europe? Australian Journal of Public Administration, 51(1), 117-130.

Metcalfe, L. and Richards, S. (1990) Improving Public Management, Sage

Michelmann, H. J. (1978). Organisational effectiveness in a multinational bureaucracy, Farnborough, U.K.: Saxon House.

Monnet, J. (1978) Memoirs, William Collins Sons and Co,

Moravcsik, A. (1991). Negotiating the Single European Act: National interests and conventional statecraft in the European Community. International Organization, 45(1), $19-56$.

Moravcsik, A. (1993). Preferences and power in the European Community: A liberal intergovernmentalist approach. Journal of Common Market Studies, 31(4), 473-524.

Moravcsik, A. (1998). The choice for Europe: Social purpose and state power from Messina to Maastricht. Ithaca, NY: Cornell University Press.

Moravcsik, A. (1999). A new statecraft? Supranational entrepreneurs and international cooperation. International Organization, 53(2), 267-306.

Murdoch, Z., Connolly, S., \& Kassim, H. (2016). Bureaucratic representation and the "democratic deficit" of the European Commission (with Zuzana Murdoch and Sara Connolly), Journal of European Public Policy, 25(3), 389-409.

Murdoch, Z., Kassim, H., Connolly, S., \& Geys, B. (2019). Socialization and attitude change in intergovernmental organizations: Evidence from a two-wave survey in the European Commission. European Journal of International Relations, 25(3), 852-877. 
Nugent, N., \& Rhinard, M. (2016). Is the European Commission really in decline? Journal of Common Market Studies, 54(5), 1199-1215.

Ongaro, E., Barbieri, D., Belle, N., \& Fedele, P. (2015). EU agencies and the European multilevel administrative system. In E. Ongaro (Ed.), Multi-level governance: The missing linkages (Vol. 4). Critical perspectives on international public sector management. Bingley, U.K.: Emerald Group.

Page, E. C. (1997). People who run Europe. Oxford, U.K.: Clarendon Press.

Pierson, P. (1996). The path to European integration: A historical institutionalist analysis. Comparative Political Analysis, 29(2), 123-163.

Pollack, M. A. (1996). The new institutionalism and EU governance: The promise and limits of institutionalist analysis. Governance, 9(4), 429-458.

Pollack, M. A. (1997). Delegation, agency, and agenda-setting in the European Community. International Organization, 51(1), 99-134.

Pollack, M. A. (2003). The engines of European integration: Delegation, agency, and agenda setting in the EU. Oxford, U.K.: Oxford University Press.

Puetter, U. (2014). The European Council and the Council. Oxford, U.K.: Oxford University Press.

Reh, C., Héritier, A., Bressanelli, E., \& Koop, C. (2011). The informal politics of legislation. explaining secluded decision making in the European Union. Comparative Political Studies, 46(9), 1112-1142.

Riker, W. H. (1980). Implications from the disequilibrium of majority rule for the study of institutions. American Political Science Review, 74(2), 432-446.

Rittberger, B. (2005) Building Europe's Parliament: Democratic Representation Beyond the Nation State, Oxford University Press

Rittberger, V., \& Zangl, B. (2012). International organization. Basingstoke, U.K.: Palgrave Macmillan.

Ross, G. (1995). Jacques Delors and European integration. Cambridge, U.K.: Polity Press.

Ross, S. A. (1973). The economic theory of agency: The principal's problem. American Economic Review, 63(2), 134-139.

Sandholtz, W., \& Zysman, J. (1989). 1992: Recasting the European bargain. World Politics, 42(1), 95-128. 
Schimmelfennig, F. (2018). European integration (theory) in times of crisis. A comparison of the euro and Schengen crises. Journal of European Public Policy, 25(7), 969-989.

Schmidt, S. K. (1996). Sterile debates and dubious generalisations: European integration theory tested by telecommunications and electricity. Journal of Public Policy, 16(3), 233-271.

Schmidt, S. K. (1998) Liberalisierung in Europa: Die Rolle der Europäischen Kommission. Schriften aus dem Max-Planck-Institut für Gesellschaftsforschung Köln, Max Planck Institute for the Study of Societies, 33(33).

Schmidt, S. K. (2000). Only an agenda setter? The European Commission's power over the Council of Ministers. European Union Politics, 1(1), 37-61.

Schön-Quinlivan, E. (2011). Reforming the European Commission. Basingstoke, U.K.: Palgrave Macmillan.

Seidel, K. (2010). The process of politics in Europe: The rise of European elites and supranational institutions. London, U.K.: I. B. Tauris.

Shore, C. (2000). Building Europe: The cultural politics of European integration. London, U.K.: Routledge.

Siotis, J. (1964). Some problems of European secretariats. Journal of Common Market Studies, 2(3), 222-250.

Smith, A. (Ed.). (2004). Politics and the European Commission: Actors, interdependence, legitimacy. London, U.K.: Routledge.

Spence, D., \& Edwards, G. (Eds.). (2006). The European Commission (3rd ed.). London, U.K.: John Harper.

Spierenburg, D. (1979). Proposals for reform of the Commission of the European Communities and its services: Report made at the request of the Commission by an independent review body under the chairmanship of Mr. Dirk Spierenburg (the "Spierenburg Report"). Brussels, Belgium: European Commission.

Stevens, A., \& Stevens, H. (2001). Brussels bureaucrats? The administration of the European Union. Basingstoke, U.K.: Palgrave Macmillan.

Stone Sweet, A. and Sandholtz, W. (1998) 'Integration, Supranational Governance, and the Institutionalization of the European Polity' in W. Sandholtz and A. Stone Sweet (eds) European Integration and Supranational Governance, Oxford University Press, pp. 126. 
Suvarierol, S. (2007) Beyond the myth of nationality: A study of the networks of European Commission officials. Delft, The Netherlands: Eburon.

Suvarierol, S. (2009). Networking in Brussels: Nationality over a glass of wine. Journal of Common Market Studies, 47(2), 411-435.

Tallberg, J. (2002). Delegation to supranational institutions: Why, how, and with what consequences? West European Politics, 25(1), 23-46.

Tallberg, J. (2007). Executive politics. In K. E. Jorgensen, M. A. Pollack, \& B. Rosamond (Eds.), The Sage handbook of European politics (pp. 195-212). London, U.K.: SAGE.

Thatcher, M., \& Coen, D. (2008). Reshaping European regulatory space: An evolutionary analysis. Western European Politics, 31(4), 806-836.

Tholoniat, L. (2009). The temporal constitution of the European Commission: A timely investigation. Journal of European Public Policy, 16(2), 221-238.

Trondal, J. (2007). The public administration turn in integration research. Journal of European Public Policy, 14(6), 960-972.

Trondal, J. (2010). An emergent European executive order. Oxford, U.K.: Oxford University Press.

Tsebelis, G. (1994). The power of the European Parliament as a conditional agenda setter. American Political Science Review, 88(1), 128-142.

Tsebelis. (1997). From p. 33.

Tsebelis, G., \& Garrett, G. (1997). Agenda setting, vetoes and the European Union's codecision procedure. Journal of Legislative Studies, 3(3), 74-92.

Tsebelis, G., \& Garrett, G. (2000). Legislative politics in the European Union. European Union Politics, 1(1), 9-36.

Tugenhadt, C. (1986). Making sense of Europe. London, U.K.: Viking.

van Ballaert, B. (2017). The European Commission's use of consultation during policy formulation: The effects of policy characteristics. European Union Politics, 18(3), 406423.

van der Harst , J. and Voerman, G. (2015) An Impossible Job? -The Presidents of the European Commission, 1958-2014, John Harper

van Zimmeren, E., Mathieu, E., \& Verhoest, K. (2015). The interaction between agencies, networks and the European Commission in emerging regulatory constellations: $\mathrm{A}$ comparative analysis of the European telecom sector and the European patent 
system. In E. Ongaro (Ed.), Multi-level governance: The missing linkages (Vol. 4).

Critical Perspectives on International Public Sector Management (pp. 125-162).

Bingley, U.K.: Emerald Group.

Verhoest, K., van Thiel, S., Bouckaert, G., \& Laegreid, P. (2012). Government agencies:

Practices and lessons from 30 countries. Basingstoke, U.K.: Palgrave Macmillan.

Wessels, W. (1997). An ever closer fusion? A dynamic macropolitical view on integration processes. Journal of Common Market Studies, 35(2), 267-299.

Westlake, M. (2016). Chronicle of an election foretold: The longer-term trends leading to the Spitzenkandidaten procedure and the election of Jean-Claude Juncker as European Commission president. LSE Europe in Question Paper No.102/2016.

Wille, A. (2013). The normalization of the European Commission: Politics and bureaucracy in the EU. Oxford, U.K.: Oxford University Press.

Figure 1. European Commission: Number of nationals among Commission staff relative to member state share of EU population. Source: Calculation by Sara Connolly from European Commission (2019) Statistical Bulletin for COMMISSION on 01/10/2019. 
Table 1. European Commission: Staff Composition by Function Group

$\begin{array}{lll} & \text { Number } & \text { Percentage } \\ \text { Senior manager } & 353 & 1 \% \\ \text { Middle manager } & 1136 & 4 \% \\ \text { Official AD } & 11,562 & 36 \% \\ \text { Official AST } & 7,844 & 24 \% \\ \text { Official AST/SC } & 344 & 1 \% \\ \text { Temporary staff AD } & 587 & 2 \% \\ \text { Temporary staff AST } & 273 & 1 \% \\ \text { Temporary staff AST/SC } & 395 & 1 \% \\ \text { Contract staff } & 7,225 & 22 \% \\ \text { Special adviser } & 66 & 0 \% \\ \text { Local staff } & 2,098 & 6 \% \\ \text { Staff under national law } & 516 & 2 \% \\ \text { Total } & 32,399 & \end{array}$

Source: European Commission (2019) HR Key figures: Staff members. 
Table 2. European Commission: Share of EU Population by Nationality (Percentage);

Numbers of Commission Staff If Proportionate to Share of EU Population Compared With Actual Share of Commission Staff

\begin{tabular}{|c|c|c|c|}
\hline & Share of EU & Share If & Actual Share \\
\hline & Population (\%) & Proportionate & \\
\hline Austria & 1.73 & 518 & 467 \\
\hline Belgium & 2.23 & 670 & 4,858 \\
\hline Bulgaria & 1.36 & 409 & 744 \\
\hline Cyprus & 0.17 & 51 & 145 \\
\hline Czechia & 2.07 & 622 & 521 \\
\hline Germany & 16.17 & 4,850 & 2,118 \\
\hline Denmark & 1.13 & 339 & 355 \\
\hline Spain & 9.14 & 2,742 & 2,482 \\
\hline Estonia & 0.26 & 77 & 263 \\
\hline Finland & 1.07 & 322 & 535 \\
\hline France & 13.05 & 3,916 & 3,111 \\
\hline United Kingdom & 12.98 & 3,894 & 712 \\
\hline Greece & 2.09 & 626 & 1413 \\
\hline Croatia & 0.79 & 238 & 339 \\
\hline Hungary & 1.90 & 571 & 772 \\
\hline Ireland & 0.96 & 287 & 527 \\
\hline Italy & 11.75 & 3,526 & 4,058 \\
\hline Lithuania & 0.54 & 163 & 430 \\
\hline Luxembourg & 0.12 & 36 & 115 \\
\hline Latvia & 0.37 & 112 & 374 \\
\hline Malta & 0.10 & 29 & 165 \\
\hline Netherlands & 3.37 & 1,010 & 615 \\
\hline Poland & 7.40 & 2,218 & 1,484 \\
\hline Portugal & 2.00 & 600 & 800 \\
\hline Romania & 3.78 & 1,133 & 1,357 \\
\hline Slovakia & 1.06 & 318 & 435 \\
\hline
\end{tabular}


Slovenia

Sweden
0.41

1.99

$100.00 \%$
122

598

29,999

Source: Calculation by Sara Connolly from European Commission (2019) Statistical Bulletin for COMMISSION on 01/10/2019. 